\title{
Isolation and Identification of Mold in Banana Bunches and Their Potential as Bioinoculants to Accelerate Decomposition of Household Organic Waste
}

\author{
L Prihastini ${ }^{1, *}$, A H Ramelan ${ }^{2}$, P Setyono $^{2}$, Pranoto $^{2}$ and A Supriyanto ${ }^{3}$ \\ ${ }^{I}$ Doctoral Program in Environmental Science, Graduate School, Sebelas Maret University, Jl. Ir. Sutami 36 A, \\ Kentingan, Surakarta, 57126, Indonesia \\ ${ }^{2}$ Departement of Environmental Science, Sebelas Maret University, Jl. Ir. Sutami 36 A, Kentingan, Surakarta, 57126, \\ ${ }^{3}$ Departement of Biologi, Airlangga University, Campus C Mulyorejo, Surabaya, 60115, Indonesia \\ *Corresponding author. Email: lilisprihastini@yahoo.co.id
}

\begin{abstract}
Large populations and final storage areas cause an increase in organic waste. Efforts are needed to improve waste decomposition. Mold is one of the microorganisms that can break down organic waste. This study aims to 1) isolate and identify molds from 8 banana bunches, 2) calculate mold populations. Banana bunches were taken from Madiun Regency. Isolation and mold conversion were carried out at the Biology Laboratory of the Department of Microbiology, Faculty of Science and Technology, Airlangga University, Surabaya. Isolation was carried out by making suspension of 8 banana bunches in which each suspension was inoculated on a petri dish with medium Potato Extract Agar. Subsequently it was incubated at $30^{\circ} \mathrm{C}$ for 3-7 days. After that the mold colonies were observed macroscopically and microcosically. After observing the mold colonies, identification and calculation of the population of each species were carried out using the Total Plate Count (TPC). From the results of the study, it was found 10 species of fungal, Aspergillus niger,Aspergillus penicilloides, Aspergillus oryzae, Rhizopus nigricans, Rhizopus oryzae, Mucor piriformis, Fucarium chlamydosporium, Penicillium citrinum, Penicillium citrinum, Penicillium chrysogenum, Penicillium expantium. The TPC of each species were $6.2 \times 10^{7} \mathrm{CFU} / \mathrm{ml}, 5.4 \times 10^{7}$ $\mathrm{CFU} / \mathrm{ml}, 4.9 \times 10^{7} \mathrm{CFU} / \mathrm{ml}, 4.2 \times 10^{7} \mathrm{CFU} / \mathrm{ml}, 3.6 \times 10^{7} \mathrm{CFU} / \mathrm{ml}, 4.1 \times 10^{7} \mathrm{CFU} / \mathrm{ml}, 4.1 \times 10^{7} \mathrm{CFU} / \mathrm{ml}, 3.3 \times 10^{7}$ $\mathrm{CFU} / \mathrm{ml}, 3.8 \times 10^{7} \mathrm{CFU} / \mathrm{ml}, 4.1 \times 10^{7} \mathrm{CFU} / \mathrm{ml}$. Insulated molds have the potential as bioinoculant acceleration of decomposition organic waste due to rapid growth.
\end{abstract}

Keywords: Mold, Banana bunches, Bioinoculant, Decomposition, Organic waste.

\section{INTRODUCTION}

Large population accompanied by increased activity results in an increase in the volume of waste. The resulting waste will be disposed of at the landfill (TPA). Nowadays it is difficult to find land for landfills so this case can lead to higher waste dumps. Waste dumps will cause environmental problems. Large volumes of waste disposal have the potential to release methane gas which can increase greenhouse gas emissions and contribute to global warming. The waste dump will produce leachate which can cause contamination of groundwater around the landfill. Leachate from the landfill has an impact on groundwater sources so that groundwater around the landfill should not be used for drinking water supplies unless handled according to drinking water standards. [2] Leachate contains heavy metals and organic contaminants. It has a potential source of groundwater pollution that makes groundwater unusable for household needs [3]. 
The waste generated is generally organic waste. Based on the composition and physicochemical characteristics, $59 \%$ of the waste is organic waste [4]. By looking at the composition of the waste which is mostly organic material, waste management by composting method is an alternative to process waste. Organic waste is a type of waste that can decompose naturally. Natural decomposition takes 3 to 4 months [5], so this method is not effective in reducing waste dumps. The addition of biodecomposers will accelerate the decomposition process in composting. Microorganisms act as biodecomposers in the process of decomposition of organic waste. Mold is one of the microorganisms that can decompose organic waste [6].

This study aims to isolate and identify molds from banana bunches and also to determine its potential as a bioinoculant. Banana bunches are one part of a banana tree that physically has a hard texture. In the banana chip industry and processed foods made from bananas, banana bunches are a problem because it is difficult to decompose. Related to this, there has been no research on the isolation of fungi from banana bunches.

\section{MATERIAL AND METHODS}

\subsection{Sampling}

Banana bunch samples were taken from gardens around community houses in Madiun Regency, East Java, Indonesia. Harvested bananas were cut and some of the bunches were put in plastic and then taken to the laboratory. Banana bunches taken were from Ambon, Rojo Temen, Kepok, Rojo Ketan (Milk), Cavendis (Morosebo), Marlin, Ulin and Mas bananas.

\subsection{Mold isolation}

Banana bunches were put into different boxes and coded A, B, C, D, E, F, G, and $\mathrm{H}$ and then left for a week so there was a growth of microorganisms. After banana bunches already have mold on them, the suspension was made by inoculating into erlenmenyer containing $100 \mathrm{ml}$ of sterile distilled water. $1 \mathrm{ml}$ of the sample suspension was diluted to $10^{-6}$. All suspensions resulting from dilution were inoculated on petri dishes with Potato Dextrose Agar (PDA) media added with chloramfenical. Furthermore, the suspension was incubated at $30^{\circ} \mathrm{C}$ for 3-7 days where the growth of mold colonies was then observed in the media.

\subsection{Purification of mold colonies}

The growing mold colonies were purified by cutting the mold and putting it into new media. PDA media were added with chloramfenical to a petri dish which was then incubated at room temperature for 3 to 7 days. The pure and growing colonies were inoculated on slanted Agar in a test tube containing PDA media.

\subsection{Identification of molds}

Molds that have been isolated and purified were identified by observing them macroscopically and microscopically. Macroscopic observations include the upper part, color of the colony, the surface shape of the mold colony (cotton, puder, bludru, wax), the line from the center of the colony towards the edge of the colony, and drops of exudate. Lower observations include zoning: a circular line from the center of the colony to the edge of the colony and the color of the colony. Microcospic observations of mold includes whether isolated hyphae, pigmented hyphae: (hyaline is colorless / blue when given staining, dark (greenish brown or blackish, grayish black), hyphoid hyphae or not, simple asexual spores (Arthrospora, Blastospora, Klamidospora, blackish gray), hyphoid hyphae or not, simple asexual spores (Arthrospora, Blastospora, Klamidospora, Sporangiospora).

\subsection{Calculation of Total Plate Count (TPC) of molds}

To find out the growth of mold, mold population was calculated using the Total Plate Count (TPC) method. 10 gram banana bunches were then inoculated into $90 \mathrm{ml}$ of sterile distilled water and mixed until homogeneous and then diluted to $10^{-7}$. Each suspension from the dilution results was taken as much as $1 \mathrm{ml}$ and then inoculated into a sterile petri dish. Next $1 \mathrm{ml}$ of chloramphenicol and $15 \mathrm{ml}$ was added to the PDA media then homogenized. After the media becomes solid, incubation was carried out at $30^{\circ} \mathrm{C}$ for $3 \times 24$ hours. The next process was counting the number of mold colonies that grow on petri dishes and multiplied by the dilution factor.

\section{RESULT AND DISCUSSION}

From the isolation and identification of molds from 8 banana bunch samples, it was found 5 genera consisting of 10 species namely Aspergillus 3 species, Penicillium 3 species, Rhizophus 2 species, Fusarium 1 species and Mucor 1 species. Ten species of the mold are Aspergillus niger, Aspergillus penicilloides, Aspergillus oryzae, Rhizopus nigricans, Rhizopus oryzae, Mucor piriformis, Fusarium chlamydosporum, Penicillium citrinum, Penicilliun chrysogenum, dan Penicillium expansum. Lavendis banana bunches are the most common mold species, that is 8 species, while there are at least 3 species of ambon bananas. The results of the isolation and mold identification of each banana bunch are presented in Table 1 .

From Table 1 it is known that the molds of the genera Aspergillus and Penicillium are found in all banana bunches. Aspergillus and Penicillium are saprophytic molds that are cosmopolitan in nature and are found in various types of habitats [6]. Aspergillus is a mold that belongs to the class of Ascomycetes which can be found everywhere and grows as saprophyte in 
Table 1. Results of isolation and mold identification of each banana bunch

\begin{tabular}{|c|c|}
\hline Sample & Mold / Fungi \\
\hline $\begin{array}{l}\text { Ambon banana } \\
\text { bunches }\end{array}$ & Aspergillus penicilloides, Aspergillus oryzae, Penicillium citrinum \\
\hline Rojo Temen bunches & $\begin{array}{l}\text { Aspergillus niger, Aspergillus oryzae, Penicillium chrysogenum, Penicillium } \\
\text { expansum, Fusarium chlamydosporum }\end{array}$ \\
\hline Kepok bunches & $\begin{array}{l}\text { Aspergillus penicilloides, Aspergillus oryzae, Penicillium chrysogenum, Penicillium } \\
\text { expansum, Fusarium chlamydosporum }\end{array}$ \\
\hline $\begin{array}{l}\text { Rojo Ketan (Susu) } \\
\text { bunches }\end{array}$ & $\begin{array}{l}\text { Aspergillus niger, Aspergillus penicilloides, Aspergillus oryzae, Penicillium } \\
\text { chrysogenum, Penicillium expansum }\end{array}$ \\
\hline $\begin{array}{l}\text { Lavendis (Morosebo) } \\
\text { bunches }\end{array}$ & $\begin{array}{l}\text { Aspergillus niger, Aspergillus penicilloides, Aspergillus oryzae, Penicillium } \\
\text { citrinum, Penicillium chrysogenum, Penicillium expansum, Rizophus nigricans, } \\
\text { Mucor piriformis }\end{array}$ \\
\hline Marlin bunches & $\begin{array}{l}\text { Aspergillus niger, Aspergillus oryzae, Penicillium chrysogenum, Penicillium } \\
\text { expansum, Rizophus oryzae }\end{array}$ \\
\hline Ulin bunches & $\begin{array}{l}\text { Aspergillus niger, Aspergillus penicilloides, Aspergillus oryzae, Penicillium } \\
\text { citrinum, Penicillium chrysogenum, Penicillium expansum, Fusarium } \\
\text { chlamydosporum }\end{array}$ \\
\hline Mas bunches & $\begin{array}{l}\text { Aspergillus niger, Aspergillus oryzae, Penicillium chrysogenum, Penicillium } \\
\text { expansum, Rizophus nigricans, Mucor piriformis }\end{array}$ \\
\hline
\end{tabular}

decaying plants, soil and food. The results of the isolation and identification of Aspergillus oryzae were found in all banana bunches. Penicillium is widespread in the natural environment and causes damage to vegetables, fruits and cereals. Penicillium chrysogenum is a species of molds that lives in various habitats [7]. Based on the results of isolation, this mold was found in
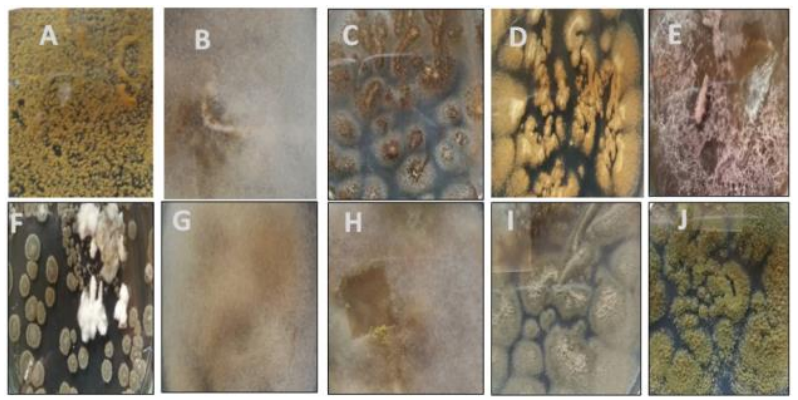

Figure 1. Macroscopic observations, A. P expansum, B. $R$ oryzae, C.A niger, D. $P$ citrinum, E. $F$ chlamydosporum, F. P chrysogenum, G. M piriformis, H. $R$ nigricans, I. A penicilloides, J.A oryzae

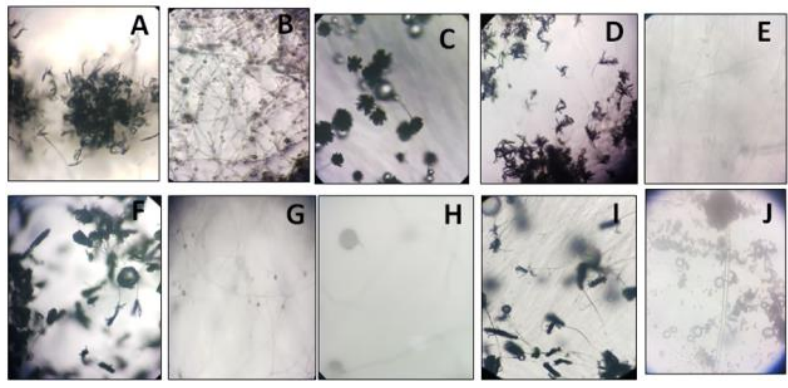

Figure 2. Microscopic observations , A. P expansum, B.A oryzae, C. A niger, D. $P$ citrinum, E. $F$ chlamydosporum, F. P chrysogenum, G. $M$ piriformis, H. $R$ nigricans, I. A penicilloides

Table 2. Results of Mold Population Calculation in Banana Bunches

\begin{tabular}{lc}
\hline \multicolumn{1}{c}{ Molds } & $\begin{array}{c}\text { Population of mold } \\
\text { (CFU/ml) }\end{array}$ \\
\hline Aspergillus niger & $6.2 \times 10^{7}$ \\
Aspergillus penicilloides & $5.4 \times 10^{7}$ \\
Aspergillus oryzae & $4.9 \times 10^{7}$ \\
Rhizopus nigricans & $4.2 \times 10^{7}$ \\
Rhizopus oryzae & $3.6 \times 10^{7}$ \\
Mucor piriformis & $4.1 \times 10^{7}$ \\
Fusarium chlamydosporum & $4.1 \times 10^{7}$ \\
Penicillium citrinum & $3.3 \times 10^{7}$ \\
Penicillium chrysogenum & $3.8 \times 10^{7}$ \\
Penicillium expansum & $4.1 \times 10^{7}$ \\
\hline
\end{tabular}


7 banana bunches. The genus Rhizopus and Mucor are also included in saprophytic molds. Mucor was only found in Lavendis and Mas banana bunches. The results of macroscopic observation of isolation and identification of molds from banana bunches are presented in Figure 1.

The result of microscopic observations of isolation and identification of molds from banana bunches are presented in Figure 2.

The results of the calculation of the number of mold colonies from the isolation and identification of banana bunches showed that the highest mold population of $A$. niger is $6.2 \times 10^{7} \mathrm{CFU} / \mathrm{ml}$ and the lowest $P$. citrinum is $3.3 \times 10^{7} \mathrm{CFU} / \mathrm{ml}$. The results of the mold population calculation are presented in full in Table 2 .

Based on Table 2, namely that the population of all molds is high, this shows that all molds from isolation and identification have rapid growth. Molds are generally saprophytic and act as decomposers of organic matter [8]. The rapid growth and saprophytic properties and decomposition of molds have the potential to be a bioniculan decomposition of organic waste.

\section{CONCLUSION}

From the results of isolation and identification of 8 banana bunches, it was obtained 10 types of fungi, namely Aspergillus niger, Aspergillus penicilloides, Aspergillus oryzae, Rhizopus nigricans, Rhizopus oryzae, Mucor piriformis, Fusarium chlamydosporium, Penicillium citrinum, Penicilliun chrysogenum, Penicillium expansum. From the results of TPC calculations, the number of colonies of all molds is high which means that it has fast growth so that it has the potential as a bioinoculant to accelerate the organic waste decomposition.

\section{ACKNOWLEDGMENTS}

The author would like to thank the Biology Department of Airlangga Surabaya Indonesia University for providing all laboratory facilities for this research.

\section{REFERENCES}

[1] Adeolu A O, Oriaku A V, Adewumi G A and Otitoloju A A 2011 African Journal of Environmental Science and Technology 5 933-940.

[2] Pande G, Sinha A and Agrawal S 2015 Global NEST Journal 17 162-174.

[3] Ghosh P and Indu S T 2014 Biogeochem Envis 20 35.

[4] Hamad T A, Abdulhakim A A, Yousif M H and John W S 2014 Case Studies in Thermal Engineering 4144 - 152.
[5] Muttalih S A A, Sharifah N S I and Sarva M P 2016 Asia Pasific Environmental and Occupatinal Health Journal 237 - 47.

[6] Ilyas M 2010 Biosfera 27 140-146

[7] John I P and Ailsa D H 1985 Fungi and Food Spoilage (Australia: Academic Press Australia).

[8] Ilyas M 2007 Biodiversitas 8 105-110. 